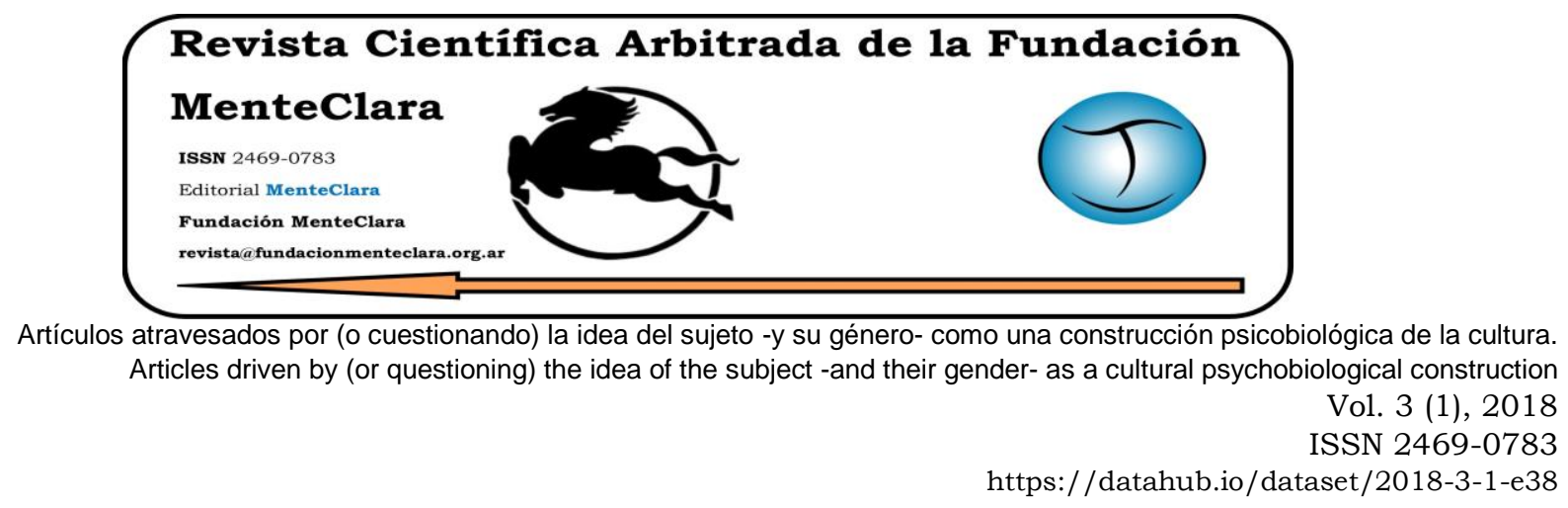

\title{
EDITORIAL GUIDELINES TO WRITE SCIENTIFIC ARTICLES
}

\author{
GUÍA EDITORIAL PARA LA PRESENTACIÓN DE ARTÍCULOS CIENTÍFICOS \\ Oscar R. Gómez oscar@tantra.org.es \\ Fundación MenteClara
}

Citation: Gómez, O. R. (2018). "Editorial guidelines to write scientific articles". Revista Científica Arbitrada de la Fundación MenteClara, 3(1), 103-113.

DOI: $10.32351 /$ rca.v3.1.41

Copyright: (C) 2018 RCAFMC. Este artículo de acceso abierto es distribuido bajo los términos de la licencia Creative Commons Attribution-Non Commercial (by-cn) Spain 3.0. Publicación online: 30/4/2018

Conflict of interests: None to declare.

\begin{abstract}
This article aims at helping authors who wish to submit their work to our journal to produce a piece of work written according to our methodological and editorial standards to ensure greater possibilities of being accepted by external evaluators and our journal's editorial committee of the Scientific Review of the MenteClara Foundation.

\section{Resumen}

Este artículo busca ayudar a los autores que deseen presentar sus trabajos en nuestra revista con una presentación acorde con nuestras normas metodológicas y editoriales para asegurarse mayores posibilidades de ser aceptados por los evaluadores externos y por nuestro comité editorial.
\end{abstract}

\section{Keywords}

Methodology; research; clinical; sociology; layout; presentation; publication; scientific article; Metodologia; investigación; clínica; sociologia; diagramación; presentación; publicación; artículo científico 


\section{Basic structure of an article of scientific interest for our journal}

Heading according to this article and:

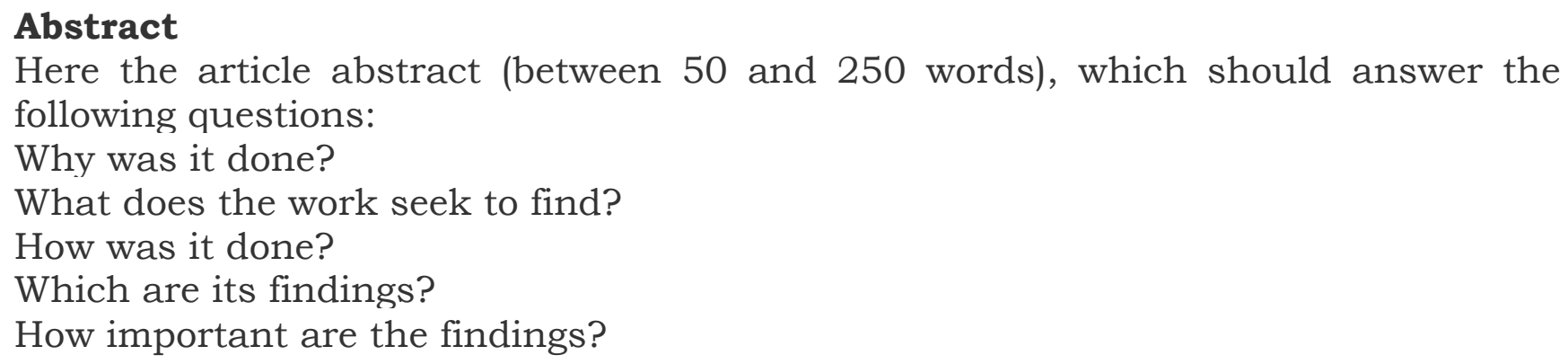

\section{Resumen}

Here the abstract of the article in Spanish

\section{Keywords}

(In English and Spanish) the words by which you want to be found by the search engines.

\section{Writing Guidelines ${ }^{1}$}

The Fundación MenteClara peer-reviewed Journal is a bilingual journal that accepts works in both Spanish and English. The journal accepts the following for publication:

Articles or original works that conform to a common academic structure (Sampieri, 2010) in scientific journals: abstract, keywords, introduction, presentation of the work principles and clear specification of its objectives; description of sources, methodology; presentation of results and discussion thereof; final conclusions and literature references. We request not to use footnotes or, if they are deemed necessary, we recommend to use as few footnotes as possible.

Book reviews: we accept works aimed at analyzing a set of new books which, either because of their subject matter or common ground, may lead to a discussion or presentation of the state of affairs of a specific topic.

\footnotetext{
${ }^{1}$ Footnotes are to be used only when highly necessary to clarify a term or methodology or that which the author considers to be indispensable for a clear understanding of his/her work.
} 
Every original document, before starting the peer-review process, will be previously read by the Editorial Board and Director, who will determine the document suitability to the standards and content profile of the journal.

The Board may reject an article without sending it to the external reviewers if the document is considered not to be in line with the publication content profile.

An original document that is to be reviewed will follow the usual system of "peers". It will be sent to at least two external evaluators. Their suggestions will be sent to authors so that, if necessary, they make all appropriate changes.

The evaluation method used is known as "double-blind", which keeps both the author and the reviewers anonymous ${ }^{2}$.

The Editorial Board will examine all contributions and, based on external evaluations, it will approve or reject them. It will also decide in which volume and issue accepted articles will be published. The author will be informed about the acceptance or rejection of his/her contribution within a maximum period of six months.

\footnotetext{
${ }^{2}$ At the end of this layout template, on page 108, you will find the review guide in English that the journal uses. Please before you send us your article, check it against this guide to vouch for a feasible, interesting, novel, ethical, and relevant piece of work.
} 


\section{How to write and send your article}

Use this layout template to send your work. Use it to set page size, margins, indents, font type, and paragraph and line spacing.

-Page size: A4

-Mirror margins. Top and bottom margins: $2 \mathrm{~cm}=0.787$ in. Inside margin: $2 \mathrm{~cm}=0.787$ in. | Outside margin: $1.5 \mathrm{~cm}=0.591 \mathrm{in}$.

-Font style: Bookman Old Style

-Font size: 14

-Alignment: Justify

-Special indentation: First line by $0.6 \mathrm{~cm}=0.24$ in. Spacing $>$ Before $6 \mathrm{pt}$. Line spacing: single.

(If in doubt, check spacing against this template you are reading.).

\section{Examples of APA citation 6th edition:}

First you must load the bibliographical sources in Word. Go to the References tab> Manage Sources $>$ Add New Source. Then fill in the bibliography information for the source. Once on your document, click at the end of the sentence or phrase you want to cite and click Insert Citation on the References tab so that it reads as follows:

(Ann Heirman, 2007) (Capra, 2000) (Chhaya, 2009)

(Congreso Mundial Uigur, 2004) (Foljambe, 2008)

(Gómez, 2013) (Jiménez Rueda, 1945) (Pandit, 1980)

(Urban, 1999) (de Mora Vaquerizo, 1988)

Finally, at the end of the article and using a blank page:

A) go to the References tab > Bibliography > Add References

B) go to the References tab> Bibliography > Add Bibliography

The references and bibliography lists will be created automatically. 


\section{Suggested basic structure of the article:}

1. Introduction. This section presents the objective of the article, its background, state of affairs in the scientific community, and the reason why this article brings something new to science. The introduction should be brief. Use the main article keywords; the most important ones will also be in the title and abstract.

2. Materials and methods. This section explains how research has been done, which materials, experiences, studies and methods were used; where and how it was done, which bibliographical sources were consulted.

3. Results. They can be data, interpretations, comments. In any case, they have to be very clear and concise. Usually, results are presented in the form of lists, tables, graphics, and images.

4. Discussion. The discussion section analyzes the results significance and their interpretation, comparing them with results from other studies, and relating this article with others and with other research done in the same context.

5. Conclusions: It is the research summary and its current state. Here you can articulate future goals to pursue in line with your research.

\section{Example of how to insert your work in a template}

First unformat the article by copying and pasting it into Notepad. Then copy and paste that unformatted text into the same text in our layout template.

You can download the layout template from:

http://fundacionmenteclara.org.ar/revista/public/journals/1/layout template.dotx 
Review guideline: Below you will find some of the questions reviewers will need to answer to assess your article (Bobenrieth Astete, 1998). Some of the questions are specific to certain academic frameworks. We suggest you answer "yes" at least to $50 \%$ of the ones corresponding to your arena. That way your article will not be rejected and it will begin the review, editing, layout, and publication process.

Does the relationship of the title, the content and conclusions meet required standards?

Does the title allow clear identification of the topic?

Does the title include the study variables?

Does the abstract reflect the structure of the article?

Does the abstract have less than 250 words?

Does the abstract describe the article's objective?

Does the abstract describe the content of the article?

Does the abstract mention the problem and the method used in the research work?

Does it use generic names for pharmaceutical products?

Do keywords identify the area of knowledge?

Do keywords correspond to the topic area?

Does the introduction properly set the research problem?

Does the introduction describe the research strategy?

Does the introduction point out the study implications (scientific and social impacts)?

Does the introduction identify the author's stance?

Does the introduction mention previous research on the area?

Does the introduction set out the purpose of the research?

Does the introduction set out the objectives of the research?

Does the methodology section show the procedures used by the author for the research design?

Does the methodology section justify the selection of variables and / or sample (s) used (s) in the research? 
Are the approach and research methods described in the methodology section?

Are instruments used for data collection described in the methodology section?

Are procedures used by the author to analyze data collected described in the methodology section?

Is the research linked to existing theories?

Is the theoretical framework suitable for the research problem?

Is the theoretical framework developed in a logical and understandable way?

Is the theoretical framework useful to clarify concepts and their relationships?

Does the article specify the unit of analysis -case, series of cases, sample or total population?

Is the target population identified and described clearly?

Is the accessible population described accurately?

Is the sample size informed in light of the study objective, study design, sampling method, and statistical analysis of data?

Does the sample indicate how representative it is regarding the target population it attempts to generalize with the study results?

Is the method of selection and allocation of subjects to study and control groups clearly described?

Are variables organized into clinically logical groups: inclusion criteria variables, risk factor variables and results variables?

Are the study and control groups comparable?

Is the study duration accurately indicated for both (study and control) groups?

Is the article internally consistent (are the abstract, introduction, objectives, methodology, and results presented complemental and duly integrated)?

Does the article have a background conceptual base supporting the argumentation?

Is the conceptual basis used by the author thoughtful, current and authoritative in his/her area of expertise?

Does the review article reflect a conscientious, thorough, and critical study of a particular topic? 
Does the article analyze published and renowned literature?

Does the article include at least one citation every two paragraphs?

Are the results are clear?

Do results correspond to the objectives?

Are results properly presented for easy understanding of readers?

Are results derived directly from collected data analysis?

Do results contribute to solve the problem?

Do the presented conclusions provide a new theoretical or practical knowledge on the topic?

Does the author adopt a stance on the research topic?

Is the article feasible?

Is the article interesting and it does not have contents the reader should already know?

Do the article and the study methodology follow appropriate ethical standards?

Is the procedure to obtain an informed consent described?

Does the article indicate that research was reviewed by any ethics board or committee?

Does the researcher describe the potential risks for research participants?

Does the article indicate that anonymity and confidentiality were insured to research participants?

Does the article propound future research on the issue based on the experience resulting from the current research?

Do citations follow the APA style guidelines?

Do bibliographic references follow the APA style guidelines?

Are in-text references well documented and updated? 


\section{Example of references format}

\section{References}

Ann Heirman, S. P. (2007). The Spread of Buddhism. Boston: Zürcher Oberland. Obtenido de https: / / books.google.es /

Bobenrieth Astete, M. A. (1998). Escritura y lectura critica de articulos cientificos. En R. Burgos Rodríguez (ed.), Metodología de investigación y escritura científica en clínica. Parte IV. Granada: Escuela Andaluza de Salud Pública.

Capra, F. (2000). El Tao de la Física. Sirio.

Chhaya, M. (2009). Dalai Lama. Hombre, monje, mistico. Grijalbo.

Congreso Mundial Uigur. (2004). Breve historia de Turkestán Oriental. Alemania: Primera Asamblea General del WUC. Obtenido de http://www.uyghurcongress.org/es/?cat=132

de Mora Vaquerizo, J. M. (1988). Tantrismo Hindú y Proteico. Universidad Nacional Autónoma de México.

Foljambe, A. (2008). Tantric Buddism, desire, and the bodyin surrealism and Georges Bataille. University of Manchester.

Gómez, O. R. (2013). El tantrismo dentro de la Compañia de Jesús - del Tíbet al Vaticano hoy (Primera ed.). (F. MenteClara, Ed.) Buenos Aires, Argentina: Ediciones Menteclara. Recuperado el 1 de 11 de 2015

Jiménez Rueda, J. (1945). La secta de los alumbrados en la Nueva España (Vols. Tomo XVI, Numeral 1). Mexico: Boletín del Archivo General de la Nación.

Pandit, M. P. (1980). Kularnava Tantra. Rito de las cinco cosas prohibidas. Editorial Eyras.

Sampieri, R. H. (2010). METODOLOGÍA de la investigación. Mexico: McGRAW-HILL / INTERAMERICANA EDITORES. 


\section{Example of bibliography format}

\section{Bibliography}

Ann Heirman, S. P. (2007). The Spread of Buddhism. Boston: Zürcher Oberland. Obtenido de https:/ / books.google.es /

Bobenrieth Astete, M. A. (1998). Escritura y lectura critica de artículos científicos. En R. Burgos Rodríguez (ed.), Metodología de investigación y escritura científica en clínica. Parte IV. Granada: Escuela Andaluza de Salud Pública.

Capra, F. (2000). El Tao de la Física. Sirio.

Chhaya, M. (2009). Dalai Lama. Hombre, monje, místico. Grijalbo.

Congreso Mundial Uigur. (2004). Breve historia de Turkestán Oriental. Alemania: Primera Asamblea General del WUC. Obtenido de http://www.uyghurcongress.org/es/?cat=132

de Mora Vaquerizo, J. M. (1988). Tantrismo Hindú y Proteico. Universidad Nacional Autónoma de México.

Foljambe, A. (2008). Tantric Buddism, desire, and the bodyin surrealism and Georges Bataille. University of Manchester.

Gómez, O. R. (2013). El tantrismo dentro de la Compañía de Jesús - del Tíbet al Vaticano hoy (Primera ed.). (F. MenteClara, Ed.) Buenos Aires, Argentina: Ediciones Menteclara. Recuperado el 1 de 11 de 2015

Jiménez Rueda, J. (1945). La secta de los alumbrados en la Nueva España (Vols. Tomo XVI, Numeral 1). Mexico: Boletín del Archivo General de la Nación.

Pandit, M. P. (1980). Kularnava Tantra. Rito de las cinco cosas prohibidas. Editorial Eyras.

Sampieri, R. H. (2010). METODOLOGÍA de la investigación. Mexico: McGRAW-HILL / INTERAMERICANA EDITORES. 


\section{References}

Sampieri, R. H. (2010). METODOLOGÍA de la investigación. Mexico: McGRAW-HILL / INTERAMERICANA EDITORES.

Bobenrieth Astete, M. A. (1998). Escritura y lectura critica de artículos científicos. En R. Burgos Rodríguez (ed.), Metodología de investigación y escritura científica en clínica. Parte IV. Granada: Escuela Andaluza de Salud Pública.

Other sources: Revista e-Ciencias de la Información. Escuela de Bibliotecología y Ciencias de la Información, Universidad de Costa Rica San José 2060, Costa Rica. Tel. (506)2511-1919 - Fax: (506) 25111949 http://revistas.ucr.ac.cr/index.php/eciencias/index 